\title{
Coexistence and Coupling of Two Distinct Charge Density Waves in $\mathrm{Sm}_{2} \mathrm{Te}_{5}$
}

\author{
Christos D. Malliakas ${ }^{1,2}$, Maria Iavarone ${ }^{3}$, Jan Fedor ${ }^{3}$ and Mercouri G. Kanatzidis ${ }^{2,3 *}$ \\ ${ }^{I}$ Department of Chemistry, Michigan State University, East Lansing, MI 48824 \\ ${ }^{2}$ Department of Chemistry, Northwestern University, Evanston, IL 60208 and ${ }^{3}$ Materials Science Division, \\ Argonne National Laboratory, Argonne, IL 60439
}

\section{Supporting Information}

\section{Table of contents}

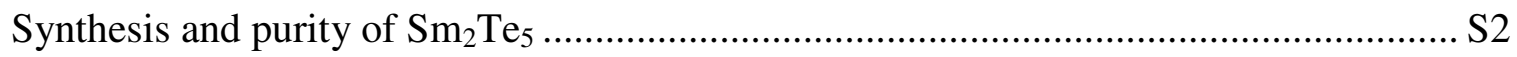

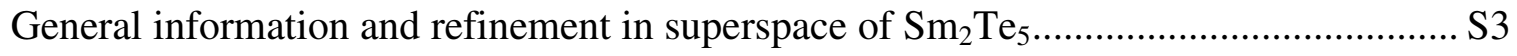

Temperature dependent single crystal X-ray diffraction experiment ............................ 4

Occupational modulation waves of vacancies in the $\mathrm{Te}^{1-}$ net of $\mathrm{Sm}_{2} \mathrm{Te}_{4.90(1)} \ldots \ldots \ldots \ldots \ldots . . . . . . . . .55$

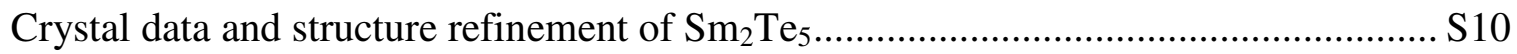

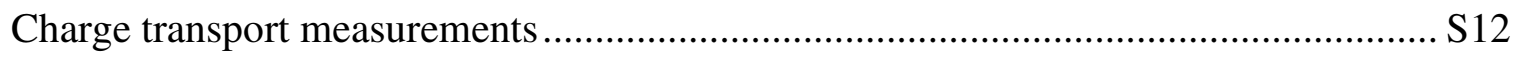

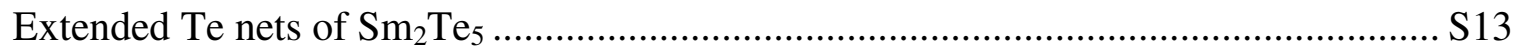

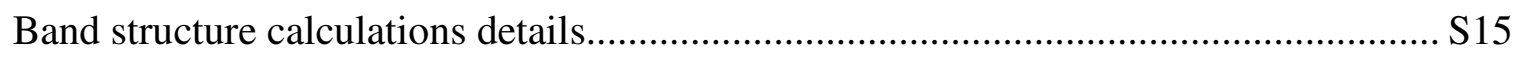

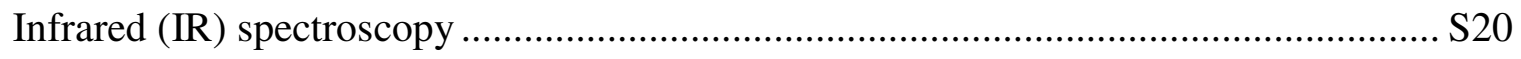




\section{Synthesis and purity of $\mathrm{Sm}_{2} \mathrm{Te}_{5}$}

All manipulations were carried out under dry nitrogen atmosphere in a Vacuum Atmospheres Dri-Lab glovebox. Stoichiometric amounts of Sm $(2 \mathrm{mmol})$ and Te $(5 \mathrm{mmol})$ were loaded into a quartz tube together with a double amount $(\sim 2 \mathrm{~g})$ of halide flux $(0.42: 0.58$ molar mixtures of $\mathrm{RbCl}$ and $\mathrm{LiCl})$. The tube was sealed under vacuum $\left(<10^{-4}\right.$ torr), heated to $650{ }^{\circ} \mathrm{C}$ at 12 hours for 6 days and cooled down to room temperature at a rate of $4{ }^{\circ} \mathrm{C} \cdot \mathrm{min}^{-1}$. The halide flux was dissolved in water and the crystals were washed with acetone and dried under nitrogen environment. The morphology of the crystals is that of thick plates with a dark brown (copperlike) color. The compound found to contain $\mathrm{SmTe}_{3}$ impurities, Figure 1S.

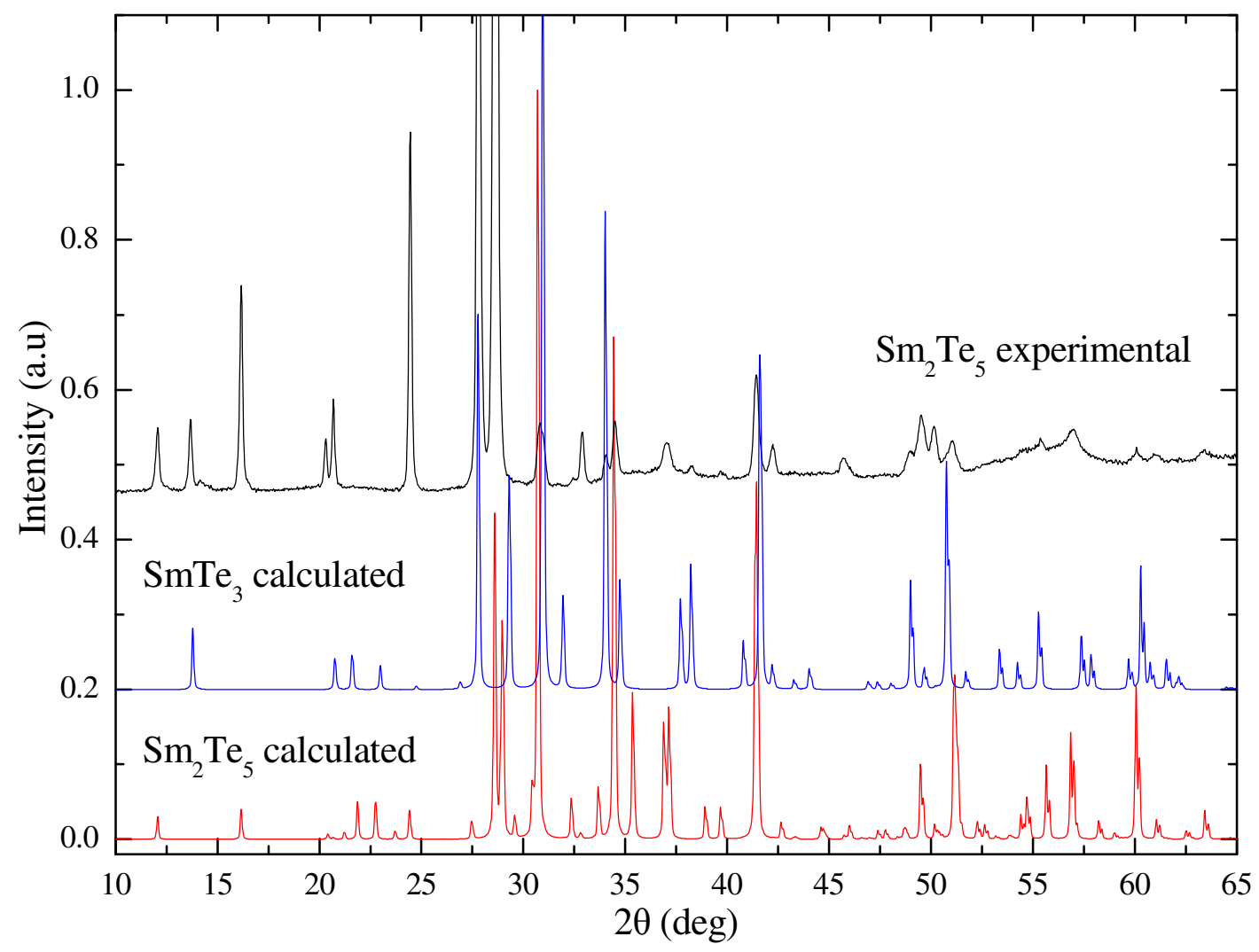

Figure 1S. Comparison of the experimental powder diffraction pattern of the as prepared $\mathrm{Sm}_{2} \mathrm{Te}_{5}$ compound with the calculated patterns of $\mathrm{SmTe}_{3}$ and $\mathrm{Sm}_{2} \mathrm{Te}_{5}$. Relative intensity of the experimental pattern is different from the calculated one due to preferential orientation of the plate-like crystals. 


\section{General information and refinement in superspace of $\mathrm{Sm}_{2} \mathrm{Te}_{5}$}

The distortion (positional or temperature parameter) of a given atomic parameter $x_{4}$ in the subcell can be expressed by a periodic modulation function $p\left(x_{4}\right)$ in a form of a Fourier expansion:

$$
p\left(k+x_{4}\right)=\sum_{n=1}^{m} A_{s n} \sin \left[2 \pi \bar{q}_{n}\left(k+x_{4}\right)\right]+\sum_{n=1}^{m} A_{c n} \cos \left[2 \pi \bar{q}_{n}\left(k+x_{4}\right)\right]
$$

where $A_{s n}$ is the sinusoidal coefficient of the given Fourier term, $A_{c n}$ the cosine coefficient, $n$ the number of modulation waves used for the refinement and $k$ the lattice translation. $\bar{q}_{n}=\sum_{i=1}^{d} \alpha_{n i} q_{i}$ where $\alpha_{n i}$ integer numbers for the linear combination of the incommensurate modulation vectors $q_{i}$.

A STOE IPDS II diffractometer was used to collect intensity data (Mo Ka radiation). An analytical absorption correction was performed, and all structures were refined with JANA2000 software (Petricek, V.; Dusek, M. Institute of Physics; Praha, Czech Republic, 2000). The length determination and refinement of the $q$-vectors was performed with the Peaklist 1.06 software part of the X-Area 1.39 suite (X-AREA, IPDS Software, STOE \& Cie GmbH, Darmstadt, 2006) using a least square refinement algorithm.

Satellite reflections of first order for both $q$-vectors and mixed order reflections $\left(q_{1}+q_{2}\right.$, $\left.q_{1}-q_{2}\right)$ were observed at $100 \mathrm{~K}$ and used for the refinement. Four modulation waves $\left(q_{1}, q_{2}, q_{1}+\right.$ $q_{2}, q_{1}-q_{2}$ ) for positional, temperature parameters and occupational (Te3a) distortions were used. Fourier terms were freely refined. The centrosymmetric P-1 superspace groups gave R-values for the satellites to more than $40 \%$. One order of satellite reflections of a single $q$-vector was observed at $500 \mathrm{~K}$. One modulation wave for positional, temperature parameters and occupational ( $\mathrm{Te}[3 \mathrm{a}]$ ) distortions was used and the Fourier terms were freely refined.

Since the only acceptable solutions was a triclinic one, the original orthorhombic system

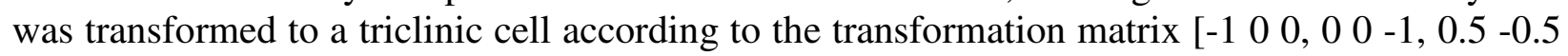
$0]$ to avoid correlations. Thus, the orthorhombic $c^{*}$-axis became a triclinic $b^{*}$-axis. The length of the $q$-vectors along the plain that contains the Te net did not change. The component of the $q$ vectors along the shortest $c^{*}$-axis was reduced by 0.5 according to the transformation matrix.

Two crystals from two different reaction batches were analyzed with single crystal X-ray diffraction studies. Both compounds found to have the same stoichiometry (e.g. concentration of vacancies) and cell parameters within the estimated statistical standard deviations.

\section{Temperature dependent single crystal X-ray diffraction experiment}

All temperature dependent measurements were performed on the same single crystal for $\mathrm{Sm}_{2} \mathrm{Te}_{5}$. The single crystal was quenched from room temperature to $100 \mathrm{~K}$ and the acquisition time was around $48 \mathrm{~h}$. The heating rate was $200 \mathrm{~K} / \mathrm{h}$. The cell parameters at $300 \mathrm{~K}$ were $\mathrm{a}=$ $4.3468(2) \AA, \mathrm{b}=4.3535(2) \AA, \mathrm{c}=21.884(1) \AA$ and $\beta=95.692(4)$ with $q_{1}=0.3116(3) b^{*}+1 / 2 c^{*}$ and $q_{2}=0.3309(3) \mathrm{a}^{*}+0.3319(3) \mathrm{b}^{*}+0.350(1) \mathrm{c}^{*}$ after indexing 13943 main, $3814\left(q_{1}\right)$ and 4048 $\left(q_{2}\right)$ satellite reflection. The cell parameters at $450 \mathrm{~K}$ were $\mathrm{a}=4.3534(4) \AA, \mathrm{b}=4.3544(4) \AA, \mathrm{c}=$ 21.985(2) $\AA$ and $\beta=95.674(8)$ with $q_{1}=0.3233(8) b^{*}+1 / 2 c^{*}$ and $q_{2}=0.3099(8) \mathrm{a}^{*}+$ $0.3268(8) b^{*}+0.281(4) c^{*}$ after indexing 16547 main, $1043\left(q_{1}\right)$ and $1182\left(q_{2}\right)$ satellite reflection. 


\section{Occupational modulation waves of vacancies in the $\mathrm{Te}^{1-}$ net of $\mathrm{Sm}_{2} \mathrm{Te}_{4.90(1)}$}

There are two different crystallographic sites, $\mathrm{Te}[3 \mathrm{a}]$ and $\mathrm{Te}[3 \mathrm{~b}]$, for the Te atoms in the $\mathrm{Te}^{1-}$ net. Interestingly, only one site, $\mathrm{Te}[3 \mathrm{a}]$, is occupationally distorted. The other site is fully occupied. The occupancy of $\mathrm{Te}[3 \mathrm{a}]$ atom modulates along the $4^{\text {th }}$ and $5^{\text {th }}$ dimension at $100 \mathrm{~K}$ creating a rather complicated pattern of vacancies. Figure $2 \mathrm{~S}$ shows an example of the profile of the occupancy of $\mathrm{Te}[3 \mathrm{a}]$ along the $t$-direction at a fixed $u=0.5$ section in which the occupancy becomes minimum. The coordinates $t$ and $u$ characterize the real three dimensional structure constructed as a perpendicular intersection with the superspace axis $A_{n}$ ( $n=4$ for $t$ and $n=5$ for $u$ ) therefore $t=x_{4}-q r$ where $r$ is a positional vector in the three dimensional space. A contour plot of the occupancy along $t$ and $u$ directions can be found in Figure 3S. The occupational modulation wave of $\mathrm{Te}[3 \mathrm{a}]$ is more simple at $500 \mathrm{~K}$ since there is only one $q$-vector. The profile of the occupancy along $t$ is shown in Figure 4S. In Figure 5S, the experimental Fourier map of $\mathrm{Sm}_{2} \mathrm{Te}_{5}$ at $100 \mathrm{~K}$ plotted along the modulation direction $(\mathrm{t})$ in comparison with the calculated (fitted) position of $\mathrm{Te}[3 \mathrm{a}]$.

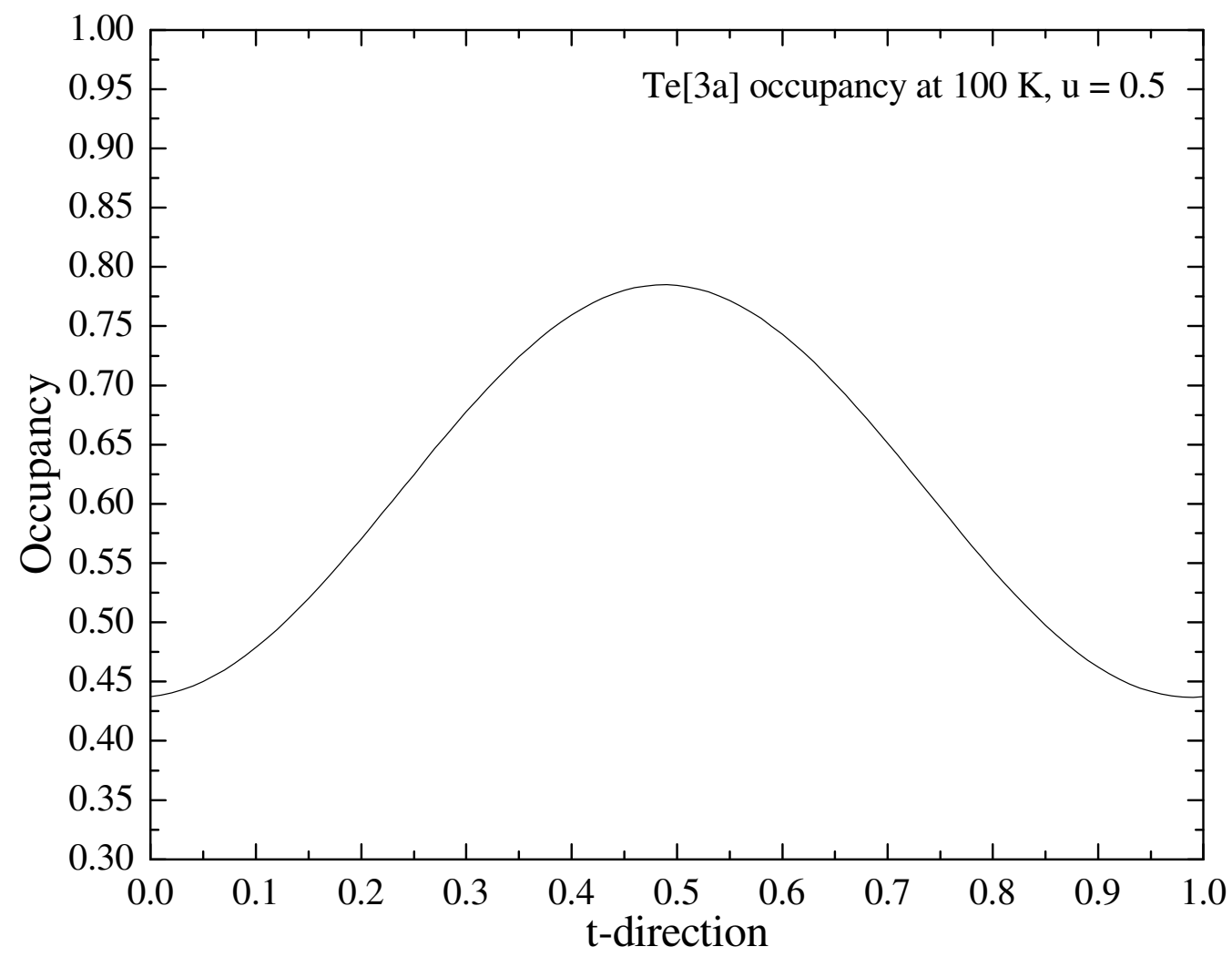

Figure 2S. Profile of the occupancy of Te[3a] in $\mathrm{Sm}_{2} \mathrm{Te}_{4.90(1)}$ at $100 \mathrm{~K}$ along the $t$-direction at a fixed $u=0.5$ section. 


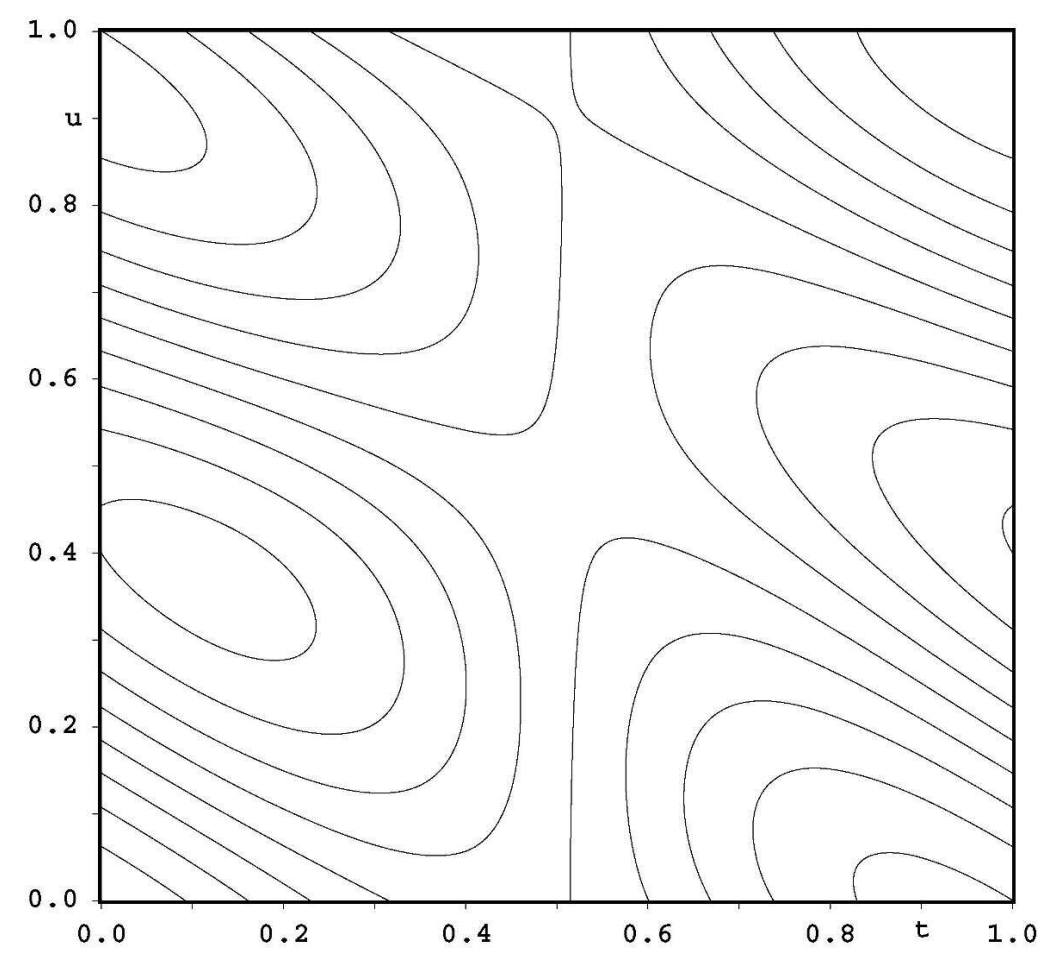

Figure 3S. Contour plot of the occupancy of $\mathrm{Te}[3 \mathrm{a}]$ in $\mathrm{Sm}_{2} \mathrm{Te}_{4.90(1)}$ along the $t$ - $u$ space. One contour line per 0.1 (occupational fraction).

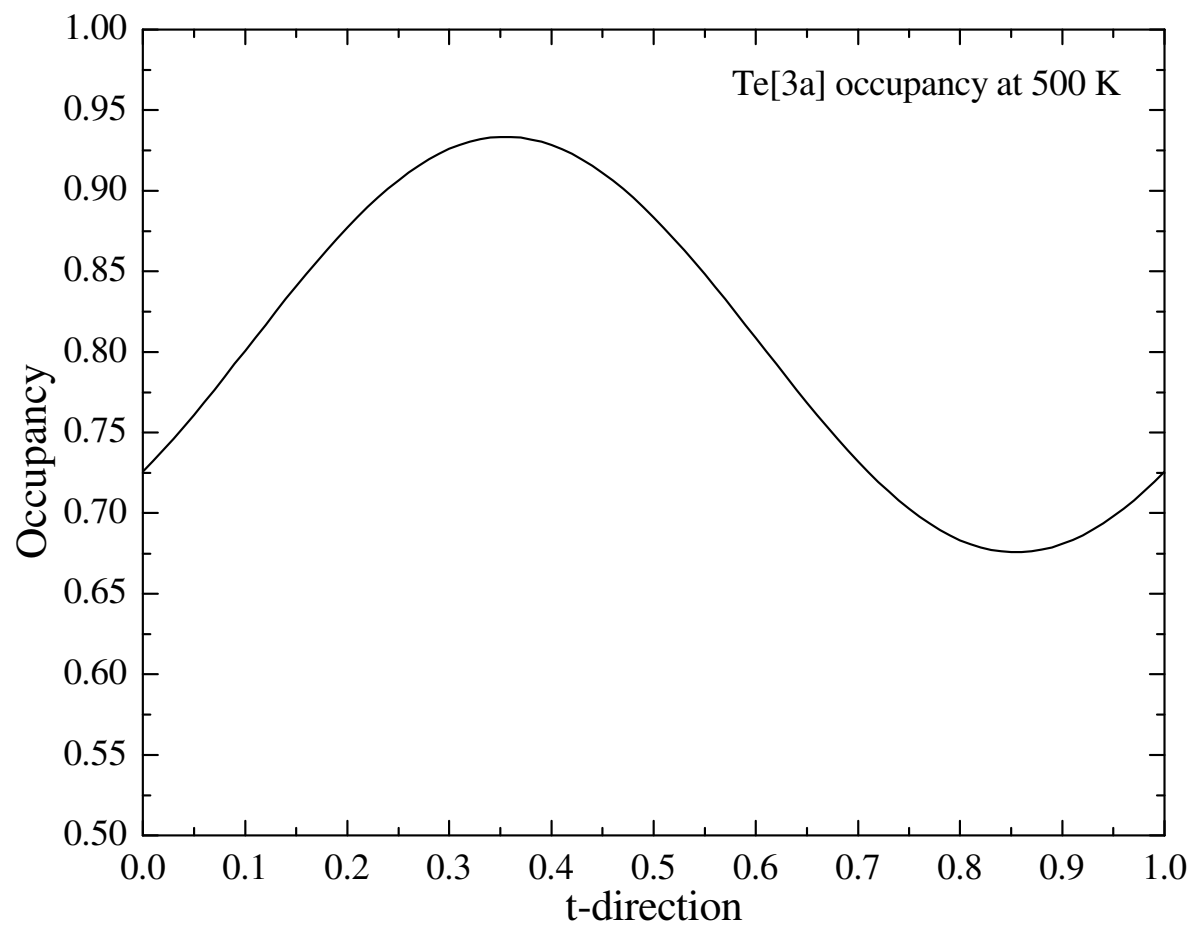

Figure 4S. Profile of the occupancy of Te[3a] in $\mathrm{Sm}_{2} \mathrm{Te}_{4.90(1)}$ at $500 \mathrm{~K}$ along the $t$-direction. 


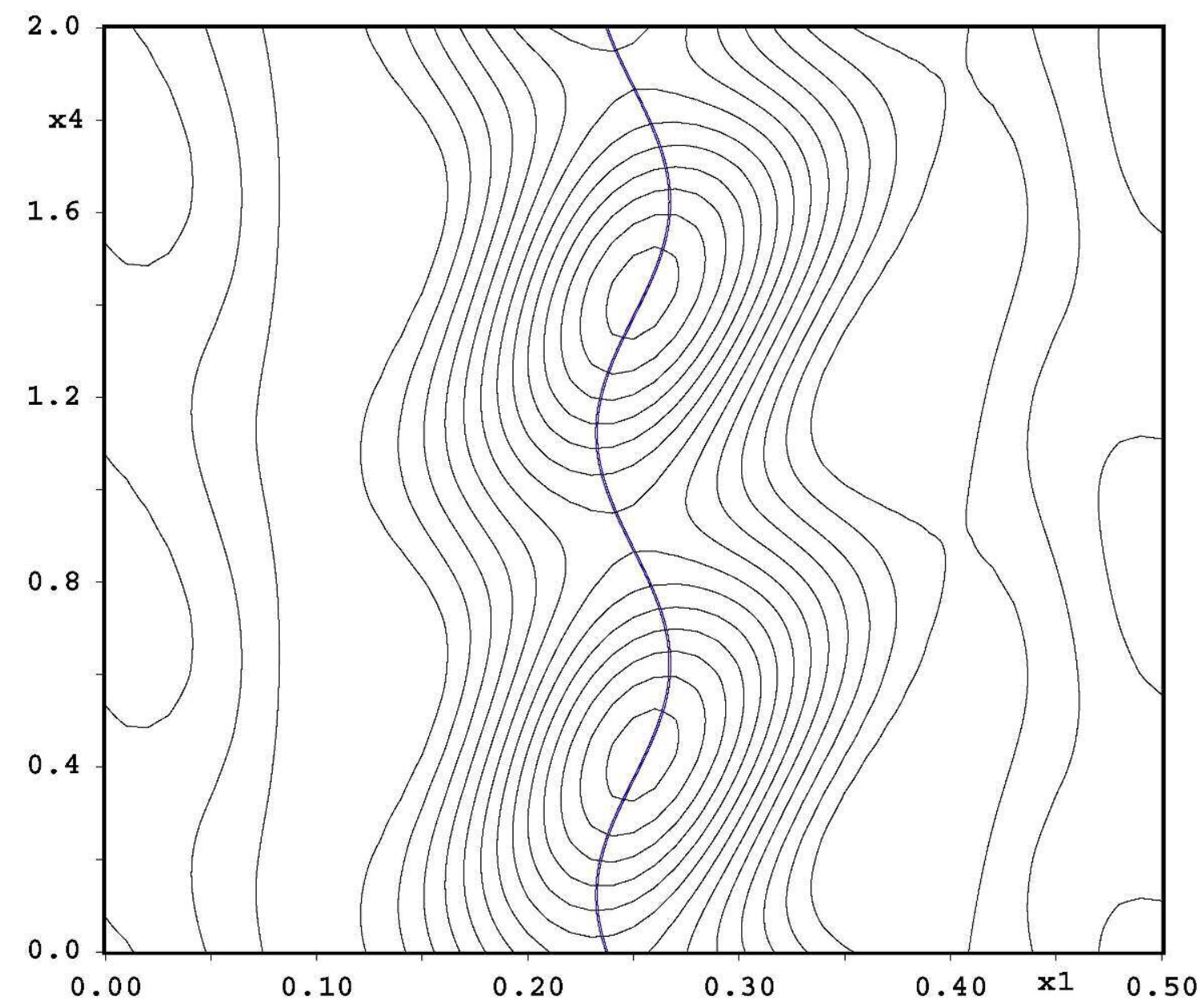

Figure 5S. Experimental Fourier map of $\mathrm{Sm}_{2} \mathrm{Te}_{4.90(1)}$ at $100 \mathrm{~K}$ plotted along the modulation direction ( $\mathrm{t}$. The central blue line represents the calculated (fitted) position of $\mathrm{Te}[3 \mathrm{a}]$. One contour line per $0.75 \mathrm{e}^{-3}$. Summation of $\mathrm{x} 2$ along $0.5-1.0$ and $\mathrm{x} 5=0.5$. 
Table 1S. Crystal data and structure refinement for $\mathrm{Sm}_{2} \mathrm{Te}_{5}$ at $100 \mathrm{~K}$.

\begin{tabular}{|c|c|}
\hline Empirical formula & $\mathrm{Sm}_{2} \mathrm{Te}_{4.90(1)}$ \\
\hline Formula weight & 938.7 \\
\hline Temperature & $100.0(3) \mathrm{K}$ \\
\hline Wavelength & $0.70926 \AA$ \\
\hline Crystal system & Triclinic \\
\hline Space group & $\begin{array}{l}\mathrm{P} 1\left(\alpha_{1} \beta_{1} \gamma_{1}, \alpha_{2} \beta_{2} \gamma_{2}\right) 0 \\
\mathrm{a}=4.3392(2) \AA, \alpha=90^{\circ}\end{array}$ \\
\hline Unit cell dimensions & $\begin{array}{l}\mathrm{b}=4.3483(2) \AA, \beta=95.679(4)^{\circ} \\
\mathrm{c}=21.8438(13) \AA, \gamma=90^{\circ}\end{array}$ \\
\hline $\mathrm{q}$-vector(1) & $0.3124(3) b^{*}+1 / 2 c^{*}$ \\
\hline q-vector(2) & $0.3303(3) \mathrm{a}^{*}+0.3315(3) \mathrm{b}^{*}+0.349(1) \mathrm{c}^{*}$ \\
\hline Volume & $410.13(4) \AA^{3}$ \\
\hline $\mathrm{Z}$ & 2 \\
\hline Density (calculated) & $7.5989 \mathrm{~g} / \mathrm{cm}^{3}$ \\
\hline Absorption coefficient & $31.474 \mathrm{~mm}^{-1}$ \\
\hline$F(000)$ & 758 \\
\hline Crystal size & $0.33 \times 0.21 \times 0.02 \mathrm{~mm}^{3}$ \\
\hline Theta range for data collection & 1.80 to $30.19^{\circ}$ \\
\hline Index ranges & $-6<=\mathrm{h}<=6,-6<=\mathrm{k}<=6,-31<=1<=30,-1<=\mathrm{m}, \mathrm{n}<=1$ \\
\hline Reflections collected & 73639 (7427 main + 66212 satellites $)$ \\
\hline Independent reflections & 34375 (3969 main +30406 satellites) $\left[R_{\text {int }}=0.0703\right]$ \\
\hline Completeness to $\theta=30.19^{\circ}$ & $95 \%$ \\
\hline Refinement method & Full-matrix least-squares on $\mathrm{F}^{2}$ \\
\hline Data / restraints / parameters & $34375 / 42 / 1100$ \\
\hline Goodness-of-fit on $\mathrm{F}^{2}$ & 1.43 \\
\hline Final $R$ indices $[I>3 \sigma(I)]$ & $\mathrm{R}_{\mathrm{obs}}=0.0587, \mathrm{wR}_{\mathrm{obs}}=0.1981$ \\
\hline $\mathrm{R}$ indices (all data) & $\mathrm{R}_{\mathrm{all}}=0.1658, \mathrm{wR}_{\mathrm{all}}=0.2421$ \\
\hline Final $\mathrm{R}$ main indices $[\mathrm{I}>3 \sigma(\mathrm{I})]$ & $\mathrm{R}_{\mathrm{obs}}=0.0490, \mathrm{wR}_{\mathrm{obs}}=0.1798$ \\
\hline $\mathrm{R}$ main indices (all data) & $\mathrm{R}_{\mathrm{all}}=0.0521, \mathrm{wR}_{\mathrm{all}}=0.1909$ \\
\hline Final $\mathrm{R} 1^{\text {st }}$ order satellites $[\mathrm{I}>3 \sigma(\mathrm{I})]$ & $\mathrm{R}_{\mathrm{obs}}=0.0872, \mathrm{wR}_{\mathrm{obs}}=0.1987$ \\
\hline $\mathrm{R} 1^{\text {st }}$ order satellites (all data) & $\mathrm{R}_{\mathrm{all}}=0.2864, \mathrm{wR}_{\mathrm{all}}=0.2633$ \\
\hline Final $\mathrm{R} 2^{\text {nd }}$ order satellites $[\mathrm{I}>3 \sigma(\mathrm{I})]$ & $\mathrm{R}_{\mathrm{obs}}=0.1410, \mathrm{wR}_{\mathrm{obs}}=0.3085$ \\
\hline $\mathrm{R} 2^{\text {nd }}$ order satellites (all data) & $\mathrm{R}_{\mathrm{all}}=0.4981, \mathrm{wR}_{\mathrm{all}}=0.4308$ \\
\hline $\mathrm{T}_{\min }$ and $\mathrm{T}_{\max }$ coefficients & 0.0095 and 0.5147 \\
\hline Largest diff. peak and hole & 6.04 and -6.75 e. $\AA^{-3}$ \\
\hline
\end{tabular}


Table 2S. Crystal data and structure refinement for $\mathrm{Sm}_{2} \mathrm{Te}_{5}$ at $500 \mathrm{~K}$.

\begin{tabular}{|c|c|}
\hline Empirical formula & $\mathrm{Sm}_{2} \mathrm{Te}_{4.90(1)}$ \\
\hline Formula weight & 926 \\
\hline Temperature & $500.0(3) \mathrm{K}$ \\
\hline Wavelength & $0.70926 \AA$ \\
\hline Crystal system & Triclinic \\
\hline Space group & $\mathrm{P} 1(\alpha \beta \gamma) 0$ \\
\hline Unit cell dimensions & $\begin{array}{l}\mathrm{a}=4.3506(9) \AA, \alpha=90^{\circ} \\
\mathrm{b}=4.3617(9) \AA, \beta=95.560(17)^{\circ} \\
\mathrm{c}=22.008(5) \AA, \gamma=90^{\circ}\end{array}$ \\
\hline q-vector(1) & $0.315(1) \mathrm{a}^{*}+0.315(1) \mathrm{b}^{*}+351(6) \mathrm{c}^{*}$ \\
\hline Volume & $415.66(15) \AA^{3}$ \\
\hline $\mathrm{Z}$ & 2 \\
\hline Density (calculated) & $7.396 \mathrm{~g} / \mathrm{cm}^{3}$ \\
\hline Absorption coefficient & $30.712 \mathrm{~mm}^{-1}$ \\
\hline $\mathrm{F}(000)$ & 758 \\
\hline Crystal size & $0.33 \times 0.21 \times 0.02 \mathrm{~mm}^{3}$ \\
\hline Theta range for data collection & 1.86 to $29.18^{\circ}$ \\
\hline Index ranges & $-6<=\mathrm{h}<=6,-6<=\mathrm{k}<=6,-30<=\mathrm{l}<=30,-1<=\mathrm{m}<=1$ \\
\hline Reflections collected & 11293 (3282 main +8011 satellites) \\
\hline Independent reflections & $9566(2788$ main +6778 satellites $)\left[\mathrm{R}_{\mathrm{int}}=0.0517\right]$ \\
\hline Completeness to $\theta=29.18^{\circ}$ & $93 \%$ \\
\hline Refinement method & Full-matrix least-squares on $\mathrm{F}^{2}$ \\
\hline Data / restraints / parameters & $9566 / 42 / 335$ \\
\hline Goodness-of-fit on $\mathrm{F}^{2}$ & 2.39 \\
\hline Final $R$ indices $[\mathrm{I}>3 \sigma(\mathrm{I})]$ & $\mathrm{R}_{\mathrm{obs}}=0.0459, \mathrm{w} \mathrm{R}_{\mathrm{obs}}=0.1663$ \\
\hline $\mathrm{R}$ indices (all data) & $\mathrm{R}_{\mathrm{all}}=0.0920, \mathrm{wR}_{\mathrm{all}}=0.2017$ \\
\hline Final R main indices $[\mathrm{I}>3 \sigma(\mathrm{I})]$ & $\mathrm{R}_{\mathrm{obs}}=0.0428, \mathrm{wR}_{\mathrm{obs}}=0.1621$ \\
\hline $\mathrm{R}$ main indices (all data) & $\mathrm{R}_{\mathrm{all}}=0.0467, \mathrm{wR}_{\mathrm{all}}=0.1912$ \\
\hline Final $\mathrm{R} 1^{\text {st }}$ order satellites $[\mathrm{I}>3 \sigma(\mathrm{I})]$ & $\mathrm{R}_{\mathrm{obs}}=0.1127, \mathrm{wR}_{\mathrm{obs}}=0.2492$ \\
\hline $\mathrm{R} 1^{\text {st }}$ order satellites (all data) & $\mathrm{R}_{\mathrm{all}}=0.4093, \mathrm{wR}_{\mathrm{all}}=0.3616$ \\
\hline $\mathrm{T}_{\min }$ and $\mathrm{T}_{\max }$ coefficients & 0.0095 and 0.5147 \\
\hline Largest diff. peak and hole & 2.82 and -3.43 e. $\AA^{-3}$ \\
\hline
\end{tabular}




\section{Charge transport measurements}

Electrical resistivity data were measured as a function of temperature for a single crystal of $\mathrm{SmTe}_{3}$. A thin layer $(\sim 10 \AA)$ of $\mathrm{Cr}$ atoms and a thicker layer $(\sim 500 \AA)$ of $\mathrm{Au}$ atoms were evaporated on a masked surface of the single crystal that was first cleaved in air. Electrical contact for the resistivity measurement was made using silver paint and $\mathrm{Cu}$ wire on the coated crystal surface. Measurements were made for arbitrary current directions in the ab-plane using a standard four point contact geometry (AC). We used a home made resistivity apparatus equipped with a Keithley 2182A Nanovoltmeter, 6220 Precision Current Source, and a high temperature vacuum chamber $\left(\sim 5 \cdot 10^{-3}\right.$ torr) controlled by a K-20 MMR System. We thank Goran Karapetrov at Argonne National Laboratory for help with the evaporation of gold contacts on the samples for resistivity.

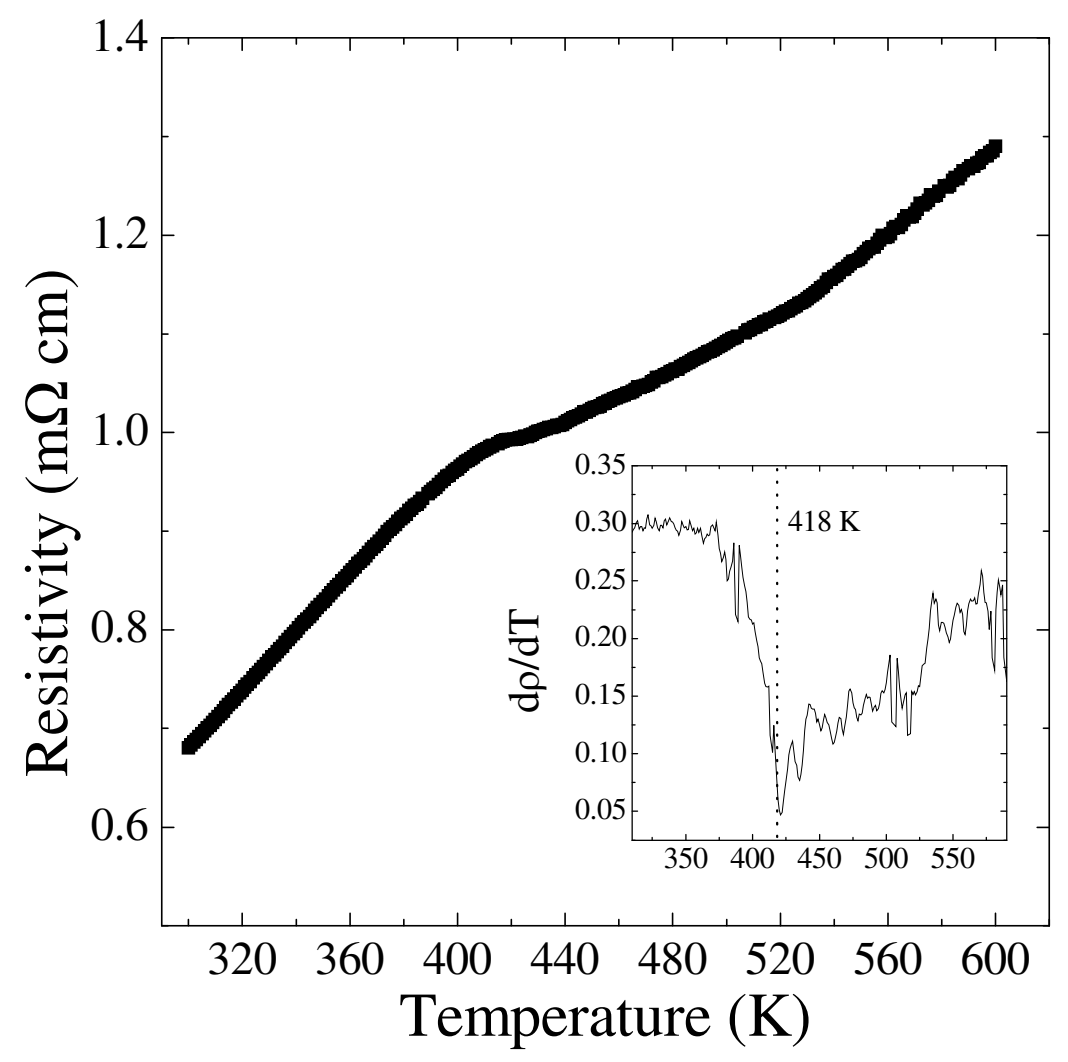

Figure 6S. High temperature resistivity data of a $\mathrm{SmTe}_{3}$ single crystal. The CDW transition temperature is around $418 \mathrm{~K}$. 
Extended Te nets of $\mathrm{Sm}_{2} \mathrm{Te}_{5}$

(A)

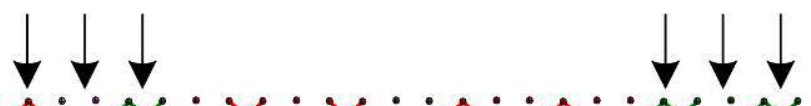

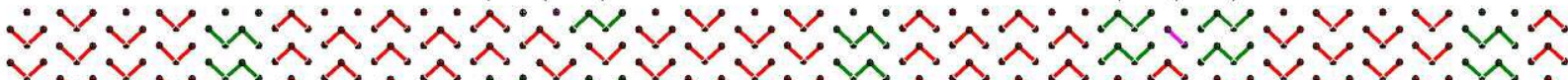
ข้v

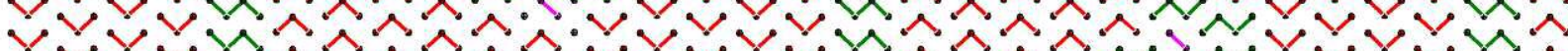
ข้ bV义

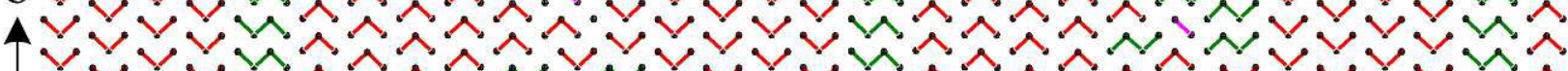

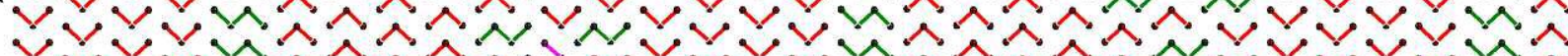

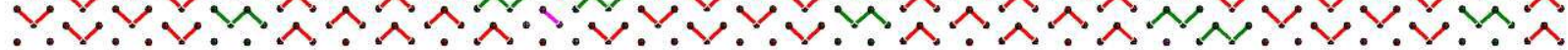
$\rightarrow \mathrm{a}$

$\mathrm{Te}^{1 / 2-}$ net of $\mathrm{Sm}_{2} \mathrm{Te}_{5}$ at $100 \mathrm{~K}$ with $3.017 \AA$ bonding threshold

(B)

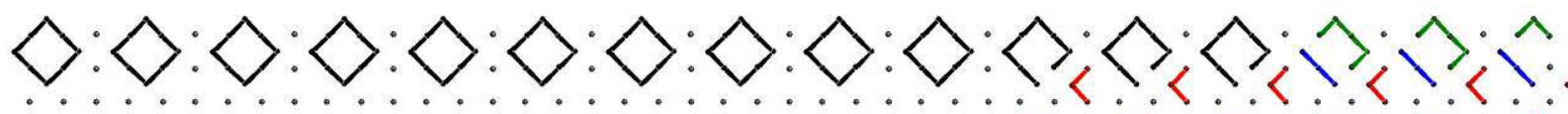

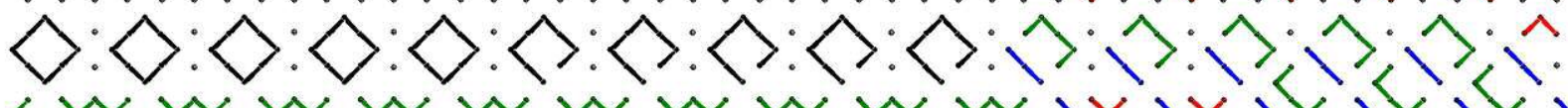

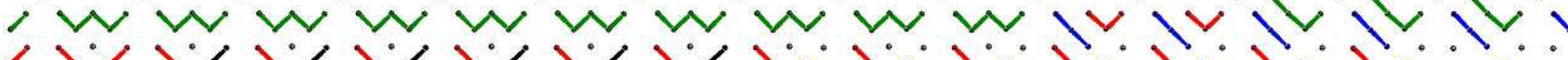

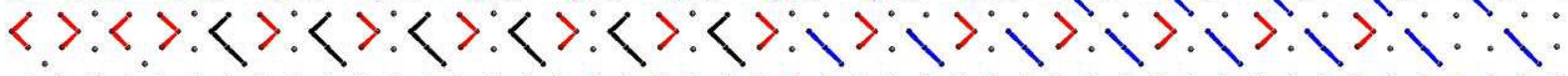
, W $W$ W

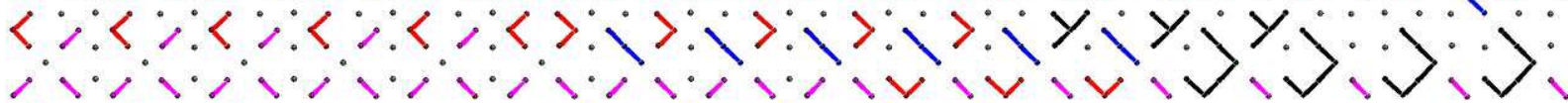

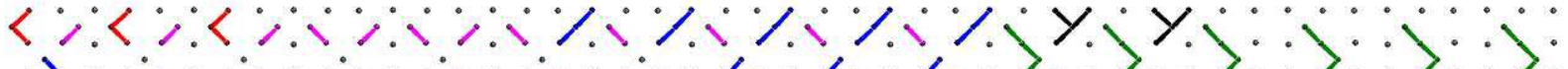

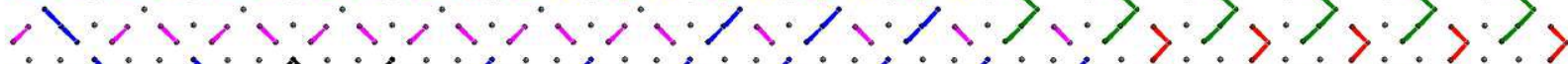
$\therefore \wedge$ 人

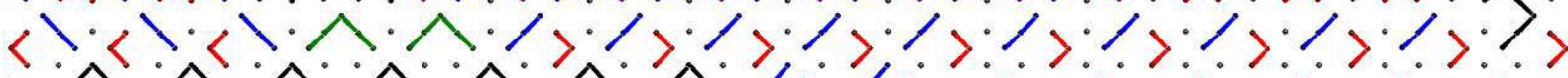

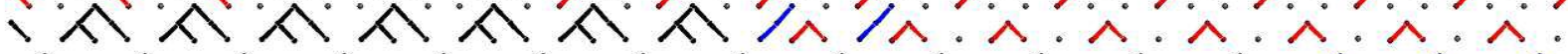

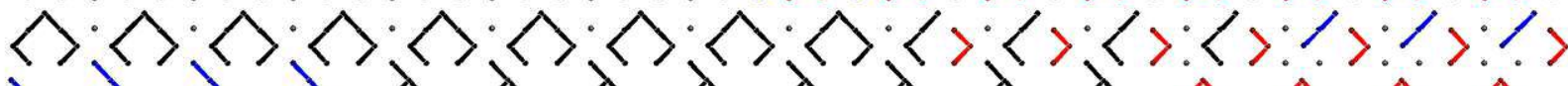

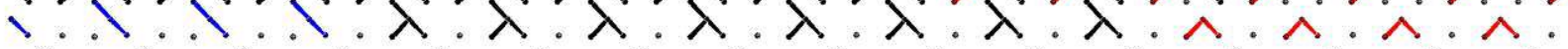

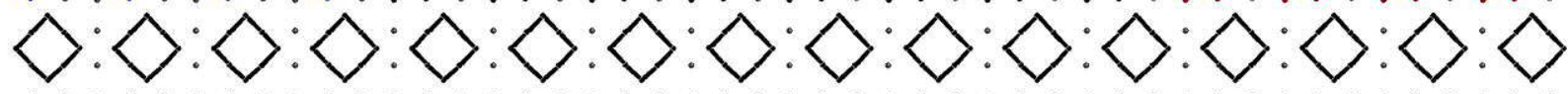

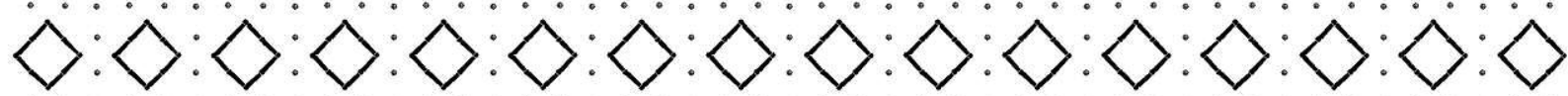

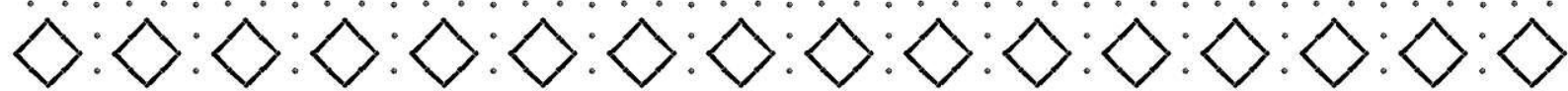

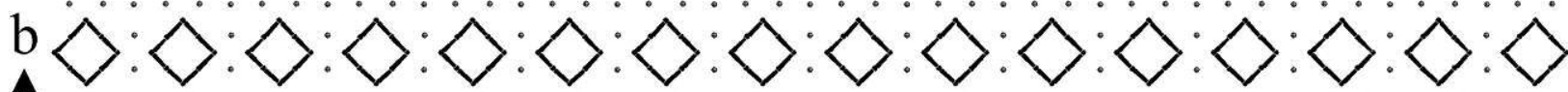

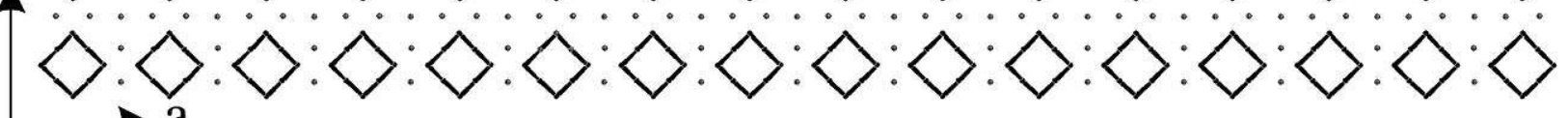
$\mathrm{Te}^{1-}$ net of $\mathrm{Sm}_{2} \mathrm{Te}_{5}$ at $100 \mathrm{~K}$ with $3.110 \AA$ bonding threshold and $80 \%$ occupational cutoff 
(C)

WINIININININININIININININININIIN IINIININININININIININININININIINI "NIININININININIININININININIINII NIININININININIININININININIININ IIININININININIININININININIININI IININININININIININININININIININII "NINININININIININININININIINININ bNINININININIININININININIINININI

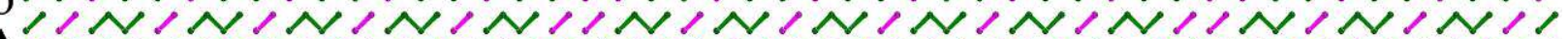
MNININININIININININININIININMNIN

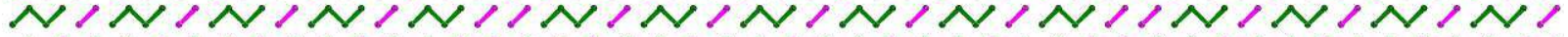
IININININIININININININIININININII $\rightarrow \mathrm{a}$

$\mathrm{Te}^{1 / 2-}$ net of $\mathrm{Sm}_{2} \mathrm{Te}_{5}$ at $500 \mathrm{~K}$ with $3.074 \AA$ A bonding threshold

(D)

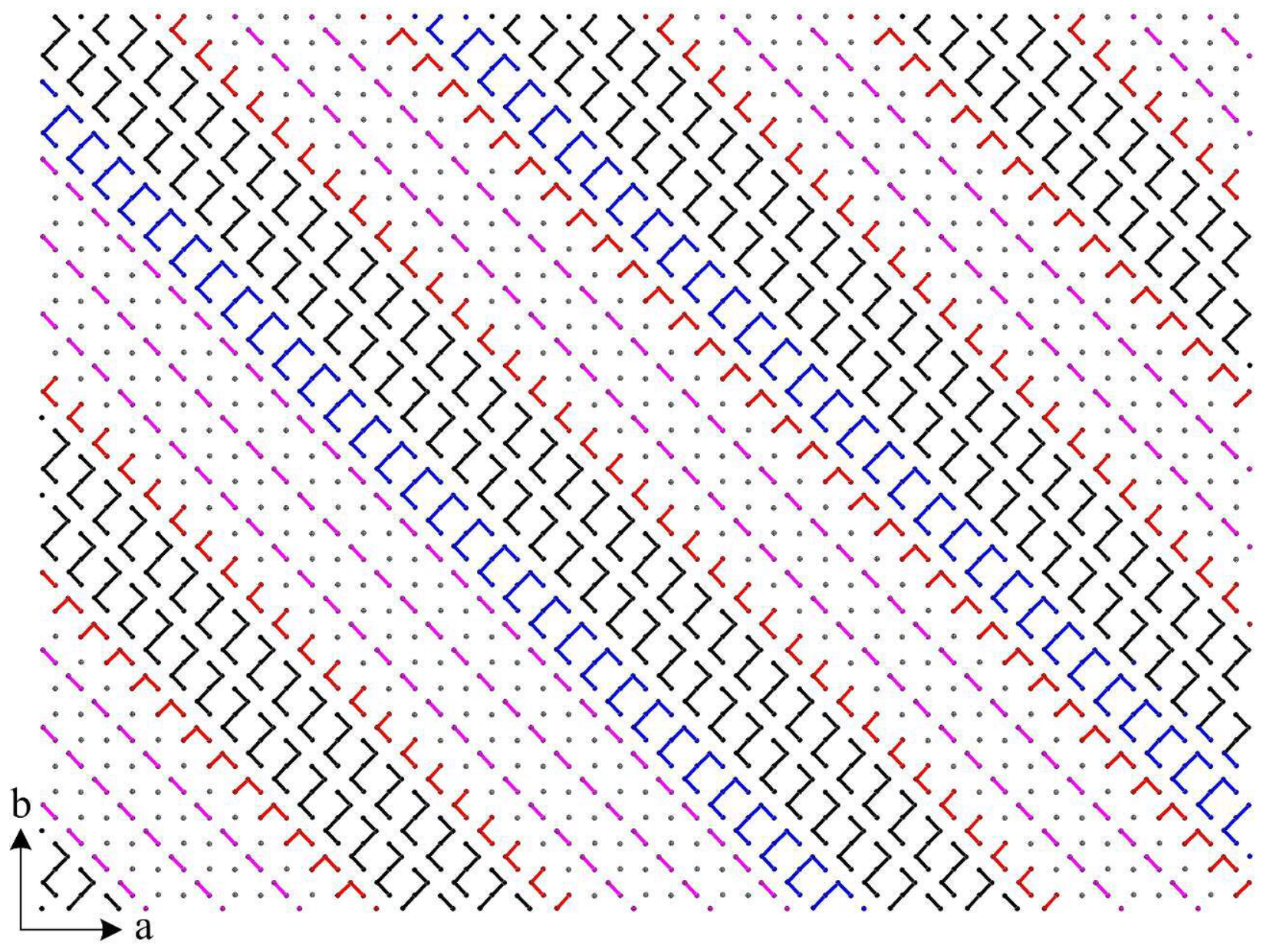

$\mathrm{Te}^{1-}$ net of $\mathrm{Sm}_{2} \mathrm{Te}_{5}$ at $500 \mathrm{~K}$ with $3.080 \AA$ 年onding threshold and $80 \%$ occupational cutoff

Figure 7S. Extended distorted nets of tellurium in $\mathrm{Sm}_{2} \mathrm{Te}_{4.90(1)}$. 


\section{Band structure calculation details}

The calculations were performed using the self-consistent full-potential linearized augmented plane wave method (LAPW) ${ }^{1}$ and the generalized gradient approximation (GGA) ${ }^{2}$ for the exchange and correlation potential. The experimental cell constants and atomic coordinates from the crystal structure refinement of the average $\mathrm{Sm}_{2} \mathrm{Te}_{5}$ at $100 \mathrm{~K}$ were used as starting values. Volume optimization was used in order to find the minimum energy of the larger $\mathrm{La}_{2} \mathrm{Te}_{5}$ cell through a Murnaghan type fitting of the Equation of States ${ }^{3}$ Interatomic forces were minimized within $0.1 \mathrm{mRy} / \mathrm{bohr}$ using a reverse-communication trust-region quasi-Newton method from the Port library. ${ }^{4}$ Scalar relativistic corrections were included and a spin-orbit interaction was incorporated using a second variational procedure. ${ }^{5}$ The values of the atomic radii were taken to be 2.7 a.u. for $\mathrm{La}$ atom and 2.5 a.u. for Te atoms, where a.u. is the atomic unit $(0.529 \AA)$. Convergence of the self-consistent iterations was performed for $150 \mathrm{k}$ points inside the irreducible Brillouin zone to within $0.0001 \mathrm{Ry}$ with a cutoff of $-6.0 \mathrm{Ry}$ between the valence and the core states. The calculations were performed using WIEN2K program. ${ }^{6}$

1. Singh, D. Planewaves, Pseudopotentials, and the LAPW method; Kluwer Academic: Boston, MA, 1994.

2. Perdew, J. P., Burke, K., Ernzerhof, M., Phys. Rev. Lett. 1996, 77, 3865-3868.

3. Murnaghan F.D., Proc. Natl. Acad. Sci. USA 1994, 30, 244.

4. http://www.bell-labs.com/project/PORT/doc/port3doc.tar.gz, Gay 1983.

5. Koelling, D. D., Harmon, B., J. Phys. C 1977, 10, 3107.

6. Blaha, P., Schwarz, K., Madsen, G., Kvasnicka, D., Luitz ,J., WIEN2K, An Augmented Plane Wave + Local Orbitals Program for Calculating Crystal Properties; Karlheinz Schwarz, Tech. Univ.: Wien, Vienna, 2001. 


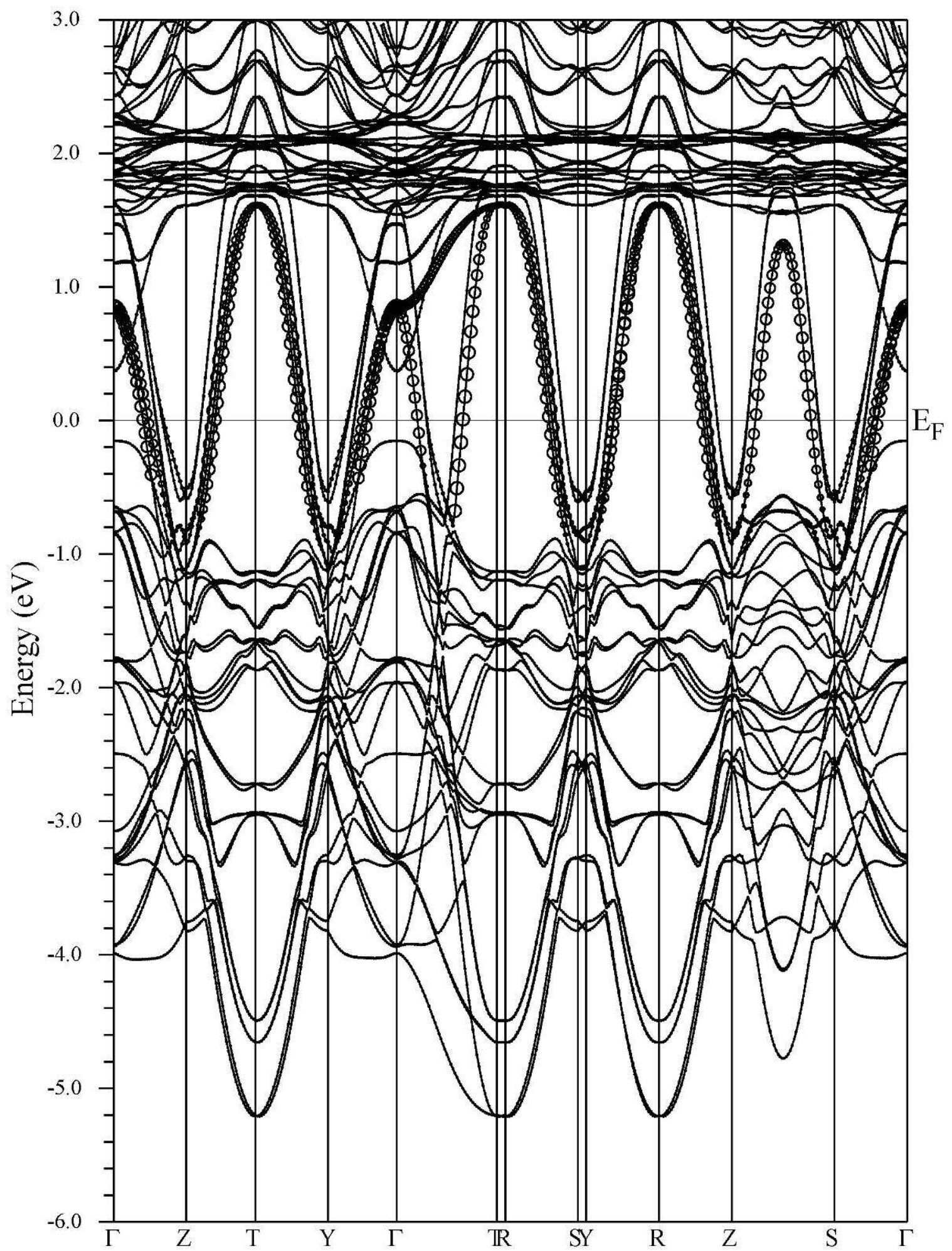

Figure 8S. Band structure of $\mathrm{La}_{2} \mathrm{Te}_{5}$ near the Fermi level. Te3 $p$ bands from the $\mathrm{Te}^{1-}$ net are drawn in open circles. The contribution of each orbital is proportional to the breadth of the circles tracing out the band. Only the bands that cross the Fermi surface are drawn in circles for clarity. 


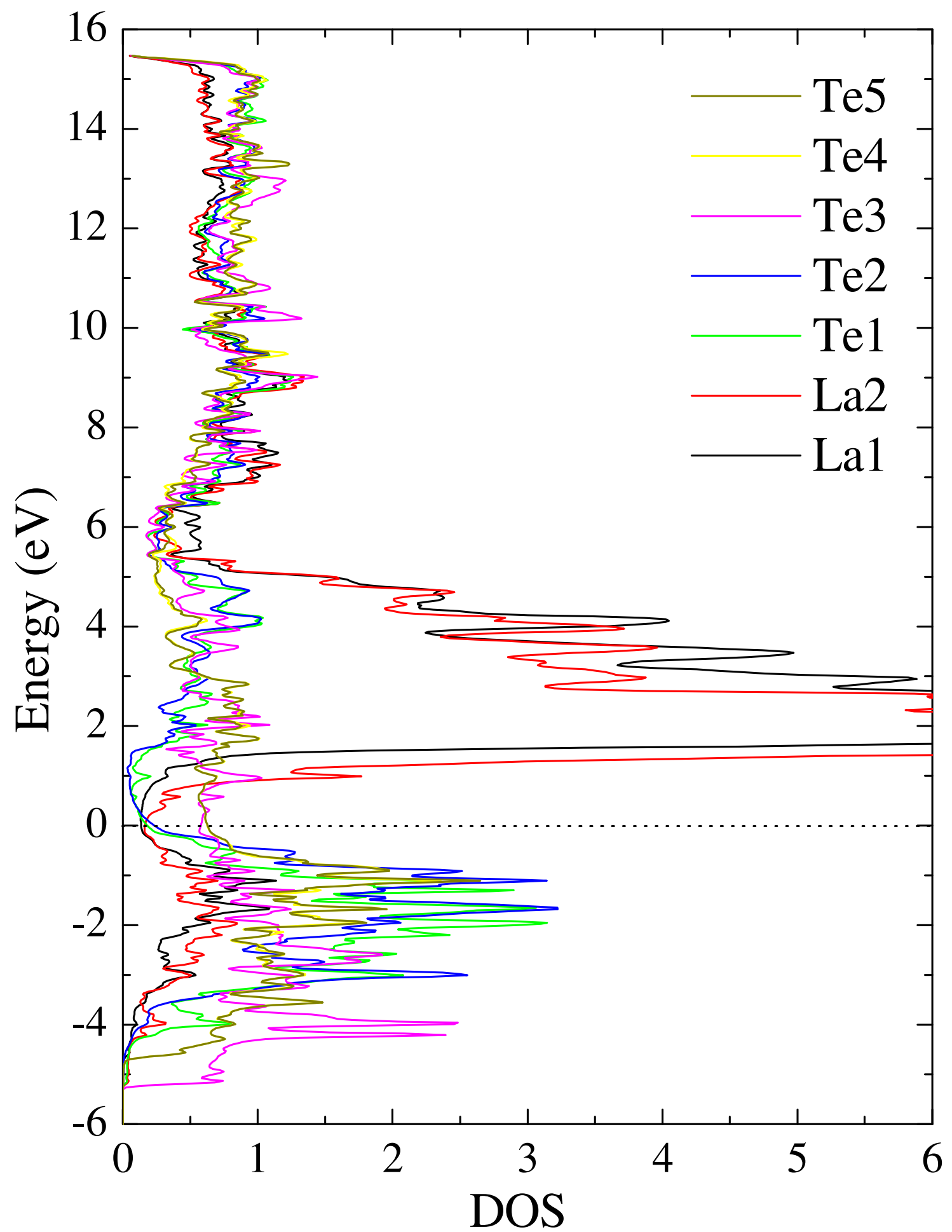

Figure 9S. Total density of states (DOS) of $\mathrm{La}_{2} \mathrm{Te}_{5}$ near the Fermi level. $\mathrm{Te} 1$ and $\mathrm{Te} 2$ are the tellurium atoms in the [RETe] puckered layers, $\mathrm{Te} 3$ is in the $\mathrm{Te}^{1-}$ net and $\mathrm{Te} 4, \mathrm{Te} 5$ are in the $\mathrm{Te}^{1 / 2-}$ net. 


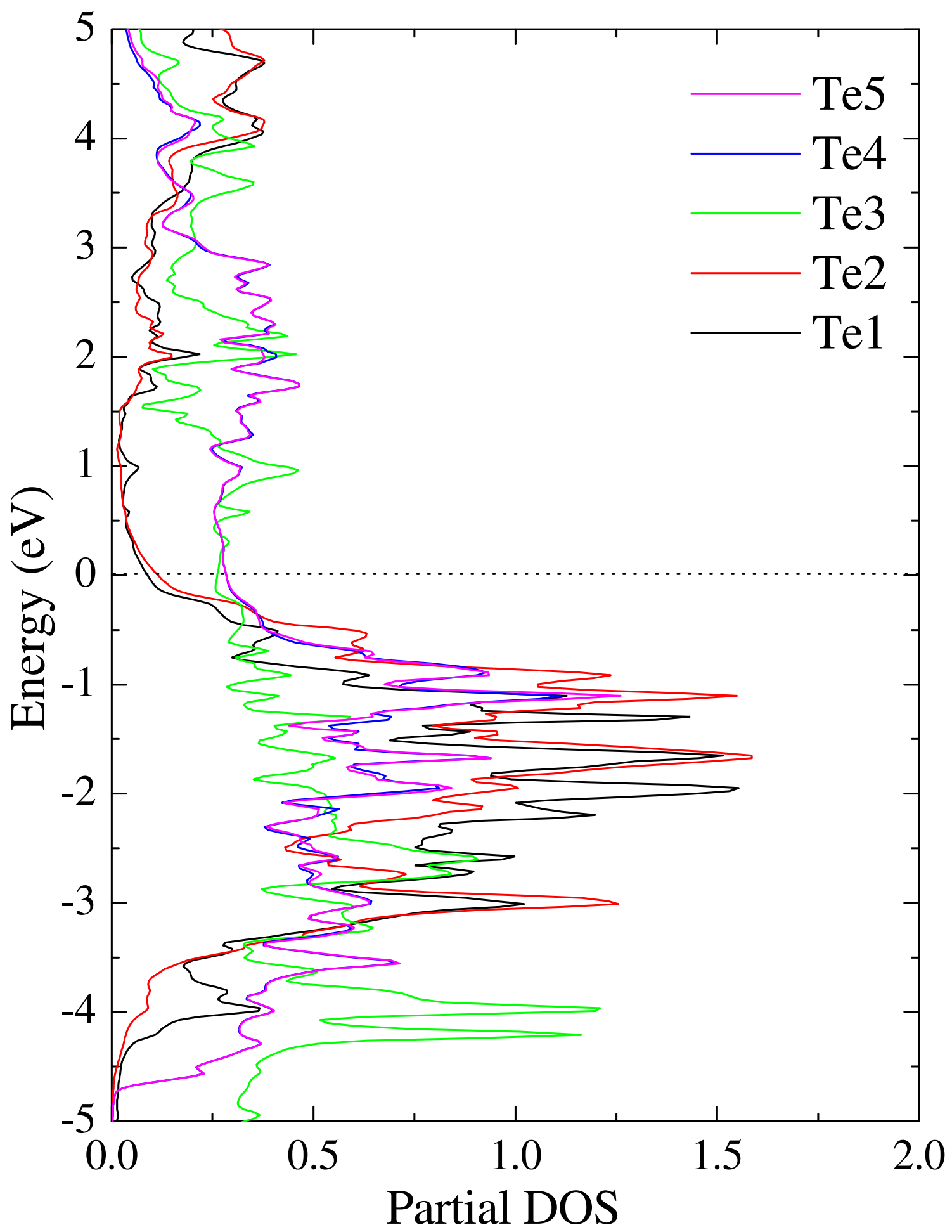

Figure 10S. Partial density of states (DOS) of all Te $p$ bands in $\mathrm{La}_{2} \mathrm{Te}_{5}$ near the Fermi level. Te1 and $\mathrm{Te} 2$ are the tellurium atoms in the $[R E \mathrm{Te}]$ puckered layers, $\mathrm{Te} 3$ is in the $\mathrm{Te}^{1-}$ net and $\mathrm{Te} 4$, $\mathrm{Te} 5$ are in the $\mathrm{Te}^{1 / 2-}$ net. 

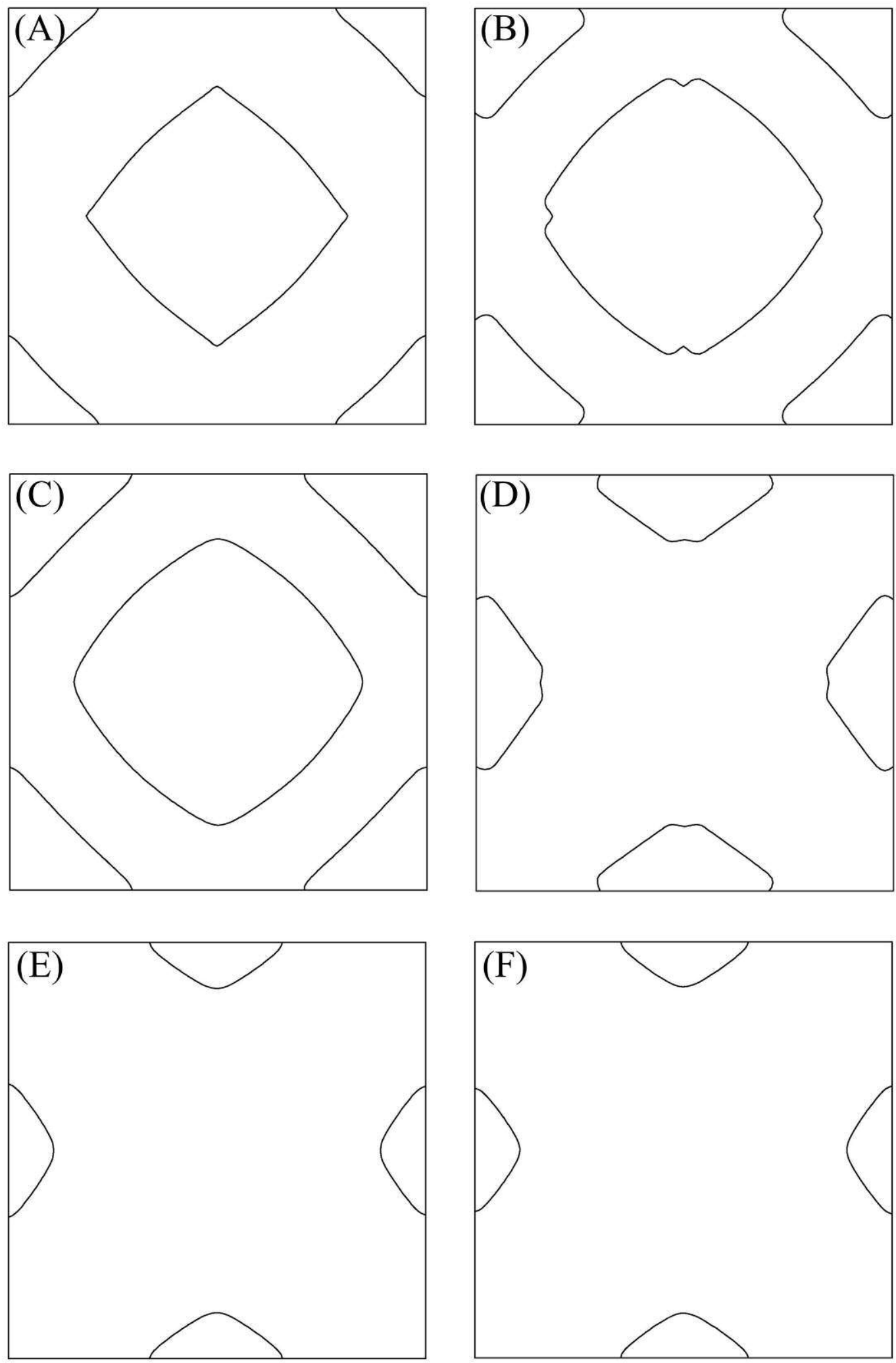

Figure 11S. Fermi surface topology of the six individual bands that cross the Fermi level. Superposition of all six bands will give the total Fermi surface as presented in Figure $3 \mathrm{~F}$ in the manuscript. $51 \times 51 \mathrm{k}$ points were used for the calculation of the Fermi surface. 


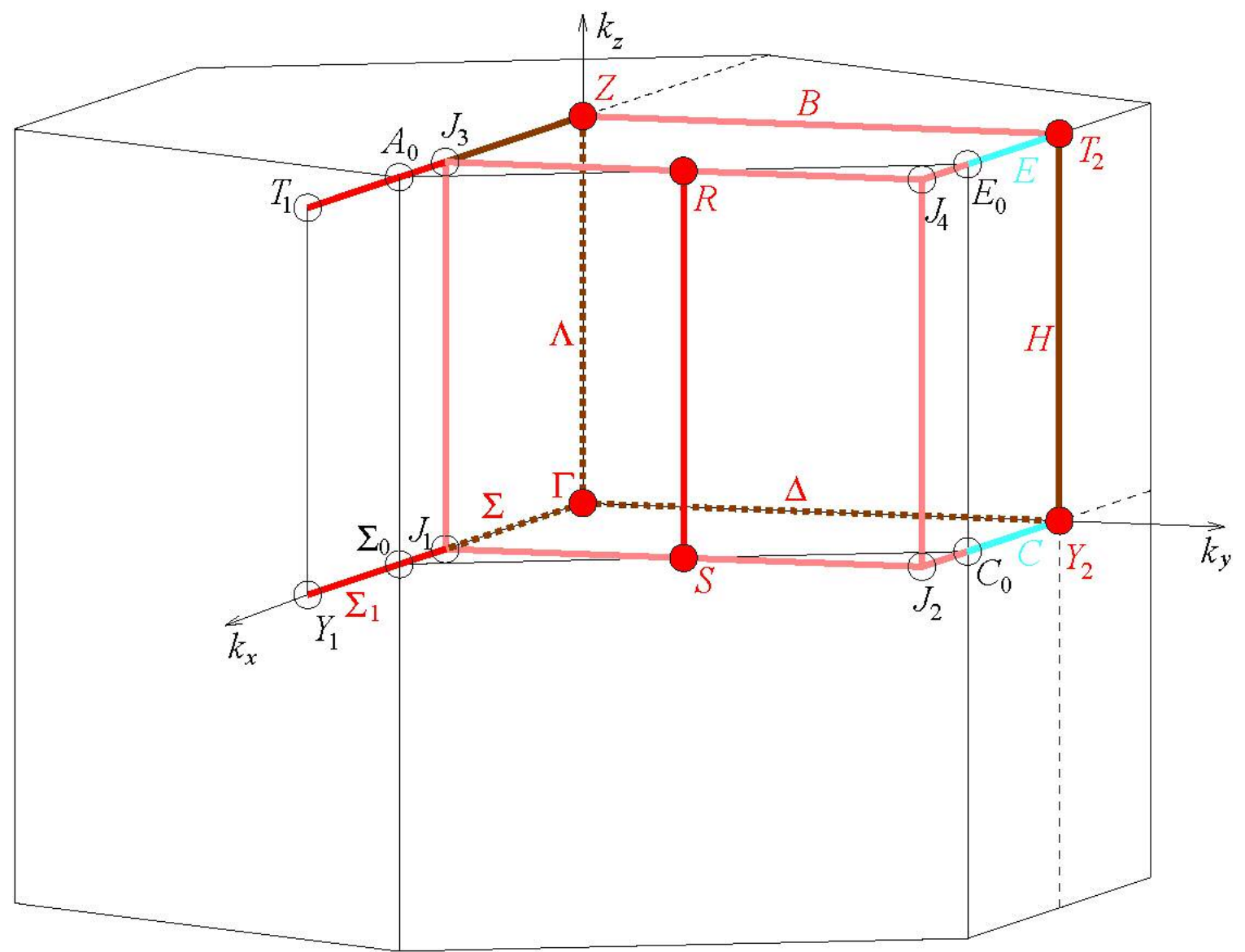

Figure 12S. Brillouin zone of $\mathrm{Cmcm}$ space group (Bilbao Crystallographic Server, http://www.cryst.ehu.es).

\section{Infrared (IR) Spectroscopy}

Optical diffuse reflectance measurements were performed on single crystals of $\mathrm{Sm}_{2} \mathrm{Te}_{5}$ and $\mathrm{SmTe}_{3}$ at room temperature. The spectra were recorded in the Mid-IR region (6000 - 400 cm-1) with a Nicolet 6700 FT-IR Spectrometer equipped with a diffuse reflectance collector from Spectra-Tech Inc. Optical band gaps were determined using the Kubelka-Munk theory. ${ }^{7}$

7. (a) Wendlandt, W. W.; Hecht, H. G. Reflectance Spectroscopy; Interscience Publishers: New York, 1966.

(b) Kotum, G. Reflectance Spectroscopy; Springer-Verlag: New York, 1969.

(c) Tandon, S. P.; Gupta, J. P. Phys. Status Solidi 1970, 38, 363. 